\title{
Web-Based vs. Face-To-Face MBA Classes: A Comparative Assessment Study
}

Barry Brownstein, University of Baltimore, USA

Deborah Brownstein, Educational Consultant, USA

Daniel A. Gerlowski, University of Baltimore, USA

\begin{abstract}
The challenges of online learning include ensuring that the learning outcomes are at least as robust as in the face-to-face sections of the same course. At the University of Baltimore, both online sections and face-to-face sections of core MBA courses are offered. Once admitted to the $M B A$, students are free to enroll in any combination of web-based or face-to-face courses. This provides a unique laboratory to assess comparative learning outcomes.
\end{abstract}

Keywords: assessment, learning outcomes, online learning, MBA

\section{INTRODUCTION}

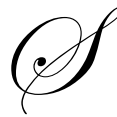

kepticism has been reported about whether distance learning formats can achieve the same learning outcomes as face-to-face courses (Allen, Bourhis, Mabry, Burell \&Timmerman, 2006). Indeed, this skepticism among academics spills over to students. Bezjian (2005) found that: "Students in traditional face-to-face courses had higher expectations for the quality of the faculty than did students in web-delivered programs."

In a comparison of learning outcomes between face-to-face and online courses, Warren and Holloman (2006) found no significant difference in learning outcomes. Brown and Liedholm (2002) and Coates and Humphreys (2003) found differences in learning outcomes when comparing online and more traditional course delivery modes. Harmon and Labrinos (2007) found no significant difference in performance between a traditional course format and one that blends traditional lecture and online learning aids. Approaching assessment from a different angle, Toper (2007) found no significant differences in the quality of instruction in face-to-face and online sections. Some research (Terry, 2007) argues that online courses more frequently enhance learning in the higher orders of Bloom's taxonomy, namely analysis and synthesis topics.

Our findings support those who maintain that learning outcomes in online courses can be at least as robust as face-to-face outcomes. During the fall semester 2005, an assessment study was conducted to compare the learning outcomes in two sections of "Domestic and Global Business Environment," a required core course in the MBA program at the University of Baltimore. Both sections were taught and evaluated by the same professor, thus holding the quality of instruction constant. One section was a purely online course and the other was purely a face-to-face course. Ordinarily, the face-to-face course would contain a supplemental online conference; but for the purpose of this study, that online conference was eliminated.

"Domestic and Global Business Environment," for both the online and the face-to-face course, contains the same twelve learning objectives. The learning objectives concentrate on Bloom's higher level learning goals: analysis, synthesis, and evaluation.

The learning environments in the online and face-to-face sections of "Domestic and Global Business Environment" are, of course, different. Although the learning environments of both sections follow a collaborative 
learning model, the web course demands more collaborative skills of both the student and professor. Later on in this paper, we discuss the differences in course design in these sections.

\section{ASSESSMENT TOOLS}

The learning objectives that were assessed were generated by two identical, writing assignments given to students in both the web-based and face-to-face sections.

The first assignment is the completion of an essay of at least ten pages in which students analyze and synthesize readings in this course up to approximately the sixth week of the course. Students are instructed that to analyze means to demonstrate that they comprehend central ideas and that they are able to express them in terms that are meaningful. They are further instructed that their analysis of the main ideas should convey their understanding of: 1) the framework for reasoning that the course is building, 2) essential elements in the works of the authors, and 3 ) how these elements are related under the umbrella of the framework. Finally, they are instructed that to synthesize means to: 1) recognize common threads across readings and, 2) combine diverse elements into a new whole. They are asked to make meaningful statements about insights that they gained which demonstrate their mastery of the analytical framework.

The second writing assignment is a final reflective essay which covers all the learning objectives. Again, this essay is to be at least ten double-spaced pages. In this essay, students demonstrate their mastery of the course material and reflect on what they have learned over the semester. To support the process of reflection, they are to compare and comment on their answers to a self-assessment questionnaire of forty-four questions that is administered at two points in time. For the face-to-face class, the first administration is at the beginning of the first class and the second is at the end of the semester. For the web class, the same questionnaire is administered during the orientation session for the web class. It is again administered at least two weeks before the final essay is due. Students typically are unsure of their answers during the first self-assessment and select answers of 3 or 4 (on a 1-7 agree-disagree scale). The second self-assessment typically shows many more answers of 1 or 7 .

Before writing their final reflective essay, students are advised to analyze their responses on their own preand post self-assessment questionnaires. They are asked to observe items on the questionnaires for which their answers changed as well as items for which their answers remained the same. In addition, many items on the questionnaire are related to each other and students are able to see how questions cluster around specific course topics. Students find this a valuable learning device.

For both writing assignments, the assessment rubric used contains the same five evaluative elements. They

are:

- $\quad$ Theme - setting out a central theme that reflects genuine personal reflection and insight arising from the student's understanding and synthesis of the required reading material.

- Content - supporting the theme by analysis of the central arguments contained in the original source material.

- Development - developing the central theme by using examples, specific references, paraphrases and quotations of the original source material.

- $\quad$ Organization - -organizing the paper so that the main theme and ideas is well developed and supported. Appropriate transitions link paragraphs and parts of the paper.

- $\quad$ Conveyance - conveying ideas in meaningful terms without jargon or superficial padding.

Table 1 sets out the complete assessment rubric. 
Table 1 - Assessment Rubric

\begin{tabular}{|c|c|c|c|c|c|}
\hline Score & $\begin{array}{l}\text { Theme, } \\
\text { integration, } \\
\text { refection and } \\
\text { insight }\end{array}$ & $\begin{array}{l}\text { Content-Essential } \\
\text { Elements, } \\
\text { Interpretation }\end{array}$ & $\begin{array}{l}\text { Development via } \\
\text { references, } \\
\text { examples etc. }\end{array}$ & Organization & $\begin{array}{l}\text { Conveyance in } \\
\text { meaningful terms }\end{array}$ \\
\hline 4 & $\begin{array}{l}\text { Clear consistent } \\
\text { theme that conveys } \\
\text { outstanding mastery } \\
\text { of course content. }\end{array}$ & $\begin{array}{l}\text { Well-developed } \\
\text { ideas demonstrate } \\
\text { outstanding mastery } \\
\text { of the source } \\
\text { material. }\end{array}$ & $\begin{array}{l}\text { Theme is } \\
\text { consistently } \\
\text { developed via } \\
\text { outstanding } \\
\text { selection of relevant } \\
\text { specific references } \\
\text { to source material } \\
\text { and examples. }\end{array}$ & $\begin{array}{l}\text { Paper is always } \\
\text { well-written and } \\
\text { well organized with } \\
\text { a compelling } \\
\text { narrative }\end{array}$ & $\begin{array}{l}\text { Ideas presented are } \\
\text { always clear without } \\
\text { use of jargon or } \\
\text { superficial padding }\end{array}$ \\
\hline 3 & $\begin{array}{l}\text { Theme that conveys } \\
\text { good understanding } \\
\text { of the course } \\
\text { content. Less } \\
\text { reflection and } \\
\text { integration than } \\
\text { category } 4\end{array}$ & $\begin{array}{l}\text { Good understanding } \\
\text { of most but not all } \\
\text { of the source } \\
\text { material. }\end{array}$ & $\begin{array}{l}\text { Good selection of } \\
\text { relevant specific } \\
\text { references }\end{array}$ & $\begin{array}{l}\text { Mostly well-written } \\
\text { and organized with a } \\
\text { good narrative flow. }\end{array}$ & $\begin{array}{l}\text { Ideas presented are } \\
\text { mostly clear without } \\
\text { use of jargon or } \\
\text { superficial padding }\end{array}$ \\
\hline 2 & $\begin{array}{l}\text { Lacks a clear theme } \\
\text { but some evidence } \\
\text { of having worked } \\
\text { with the course } \\
\text { material. }\end{array}$ & $\begin{array}{l}\text { Limited } \\
\text { understanding of } \\
\text { some of the source } \\
\text { material. }\end{array}$ & $\begin{array}{l}\text { Fair selection of } \\
\text { relevant specific } \\
\text { references }\end{array}$ & $\begin{array}{l}\text { Organization needs } \\
\text { to improve to } \\
\text { improve the clarity } \\
\text { of the paper }\end{array}$ & $\begin{array}{l}\text { Some use of jargon } \\
\text { or superficial } \\
\text { padding. Ideas are } \\
\text { sometimes unclear. }\end{array}$ \\
\hline 1 & $\begin{array}{l}\text { Lacks a clear theme } \\
\text { and little or no } \\
\text { evidence of having } \\
\text { worked with the } \\
\text { course material. }\end{array}$ & $\begin{array}{l}\text { Little understanding } \\
\text { demonstrated of } \\
\text { ideas in the course } \\
\text { material. }\end{array}$ & $\begin{array}{l}\text { Poor selection of } \\
\text { relevant specific } \\
\text { references }\end{array}$ & $\begin{array}{l}\text { Poor organization } \\
\text { that makes reading } \\
\text { the paper difficult }\end{array}$ & $\begin{array}{l}\text { Ideas presented are } \\
\text { frequently unclear. } \\
\text { Jargon and padding } \\
\text { are common. }\end{array}$ \\
\hline
\end{tabular}

\section{RESULTS}

Tables 2 and 3 set out the frequency distributions of student scores and their means in each of the five assessment categories for each class. Tables 2 and 3 also report on the tests of significance that were performed between the means in each class in each assessment category. There were no statistically significant differences.

Table 2- Results First Essay

Frequency distributions of student scores:

Online class - 26 students - "Domestic and Global Business Environment": fall 2005

\begin{tabular}{|c|c|c|c|c|c|}
\hline Score & Theme & Content & References & Organization & Conveyance \\
\hline 4 & 5 & 8 & 2 & 6 & 2 \\
\hline 3 & 17 & 11 & 14 & 12 & 18 \\
\hline 2 & 4 & 7 & 10 & 8 & 6 \\
\hline 1 & 0 & 0 & 0 & 0 & 0 \\
\hline Avg. & 3.04 & 3.04 & 2.7 & 2.92 & 2.85 \\
\hline
\end{tabular}


Face- to -Face based class- 27 students - "Domestic and Global Business Environment": fall 2005

\begin{tabular}{|c|c|c|c|c|c|}
\hline Score & Theme & Content & References & Organization & Conveyance \\
\hline 4 & 12 & 3 & 5 & 4 & 4 \\
\hline 3 & 10 & 15 & 13 & 17 & 17 \\
\hline 2 & 5 & 7 & 8 & 5 & 6 \\
\hline 1 & 0 & 2 & 1 & 1 & 0 \\
\hline Avg. & 3.26 & 2.7 & 2.8 & 2.89 & 2.92 \\
\hline
\end{tabular}

Test of significant differences between the two classes:

t score for two-sample assuming equal variance

\begin{tabular}{|c|c|c|c|c|}
\hline Theme & Content & References & Organization & Conveyance \\
\hline-1.17 & 1.57 & -.63 & .43 & -.50 \\
\hline
\end{tabular}

T critical value (two-tale test) 2.008

There are no significant differences in the avg. score for any of the 5 assessments categories.

Table 3 - Results Final Reflective Essay

Frequency distributions of student scores:

Online class - 26 students

\begin{tabular}{|c|c|c|c|c|c|}
\hline Score & Theme & Content & References & Organization & Conveyance \\
\hline 4 & 4 & 7 & 6 & 7 & 6 \\
\hline 3 & 21 & 15 & 17 & 18 & 19 \\
\hline 2 & 1 & 4 & 3 & 1 & 1 \\
\hline 1 & 0 & 0 & 0 & 0 & 0 \\
\hline Avg. & 3.12 & 3.12 & 3.12 & 3.23 & 3.19 \\
\hline
\end{tabular}

Face-to-face class - 26 students

\begin{tabular}{|c|c|c|c|c|c|}
\hline Score & Theme & Content & References & Organization & Conveyance \\
\hline 4 & 6 & 8 & 4 & 2 & 2 \\
\hline 3 & 20 & 12 & 15 & 24 & 24 \\
\hline 2 & 0 & 6 & 7 & 0 & 0 \\
\hline 1 & 0 & 0 & 0 & 0 & 0 \\
\hline Avg. & 3.23 & 3.08 & 2.88 & 3.08 & 3.08 \\
\hline
\end{tabular}

Test of significant differences between the two classes:

$\mathrm{t}$ score for two-sample assuming equal variance

\begin{tabular}{|c|c|c|c|c|}
\hline Theme & Content & References & Organization & Conveyance \\
\hline-.97 & .198 & 1.34 & 1.35 & 1.05 \\
\hline
\end{tabular}

T critical value (two-tale test) 2.009

There are no significant differences in the avg. score for any of the 5 assessments categories

\section{DIFFERENCES IN LEARNING ENVIRONMENTS}

The absence of significant differences between learning outcomes in this study suggests that we can arrive at the same destination with two different teaching and learning environments. 
The learning environment of the face-to-face course investigated in this study is as follows. Each topic begins with the student reading and analyzing original source essays. Students are encouraged to go beyond just reading and analyzing the essays and to begin to synthesize across the essays by seeing how ideas fit together. However, synthesis is not required or necessary at this point; all that is needed is a good faith attempt to understand the essays. Next, in the face-to-face environment, at the start of each new topic, students break out in small groups of approximately seven or eight, to dialogue over questions that the professor has posed concerning the topic. The group dialogue runs for 45 minutes to one hour. Students are instructed to share their insights based on their experiences and they are expected to make specific references to the course readings that helped to inform their answers. There are ten such group breakouts over the semester. When the class reconvenes, each group selects a spokesperson who shares their group findings to the class in a 5 minute informal report. Finally, the professor lectures on the topic using original PowerPoint slides. Students are free to raise questions during these talks. There are no ad-hoc lectures or topics; so each week, as a student's understanding grows, the new lecture material is designed to impact the students' understanding of past material and set the stage for future topics.

Although there are many aspects of collaborative learning in the face-to-face class, over $50 \%$ of the class time is devoted to lectures and the professor still plays a central role in the learning process. In the purest form of classroom learning, professors in this model of a learning environment have been likened to a "sage on the stage." The job of the "sage" is to funnel knowledge to students.

Bento, Brownstein, Schuster, Zacur $(2005,32)$ explained that this model, where the professor plays a central role, is built on a limited perspective on the nature of knowledge. Nobel laureate Friedrich Hayek (1945) explained that not all knowledge is scientific or expert in nature, thus making it impossible for any system to be expertly designed and managed from the top down. Hayek writes:

....there is beyond question a body of very important but unorganized knowledge which can not possibly be classified scientific...It is with respect to this (unorganized knowledge) that every individual has some advantage over others because he possess unique information of which beneficial use might be made. (ibid, p. 521)

In other words, in its pure form, the "sage on the stage," however expertly he or she funnels knowledge, fails to take advantage of important knowledge that is distributed throughout the class. The resulting learning environment is, thus, less robust than it could otherwise be.

When professors move into a web learning environment, it is common for them to attempt to duplicate online the central role that they play in a face-to-face classroom environment, where they remain the focus of attention. Their reliance upon their existing paradigm for teaching and learning is not surprising; they have yet to discover the new pedagogical possibilities that are inherent in the web environment. When they bring their existing paradigm into the web environment, their online professor-centric classes, in the end, become little more than directed self-study courses. Students' on-line participation and interaction are choked off by the design of such a learning environment. Although some education takes place, such an online learning environment misses the opportunities and the advantages of the web.

There are reasons why the professor playing the role of the "sage on the stage" is particularly inappropriate in a web-based learning environment. In order to have an effective learning atmosphere, in a web environment, the student must be guided to take on a more responsible role. Because the student's role is less passive and more active, their ability to grow their own new knowledge is potentially higher in a web environment. To take full advantage of this potential of an online classroom, the professor plays a role akin to a "guide on the side." Paradoxically, this role is potentially more time consuming than the traditional "sage on the stage" role. This is because in order to effectively guide a web-student, a professor needs to build participation and interaction into the design of the course and then give students individual feedback on their weekly postings. Collison, Elbaum, Haavind, and Tinker (2000, p. 8) succinctly discuss the advantages of the "guide on the side" model:

As participants react to content, share challenges, teach each other, and learn tangibly by putting into words (discussion postings) their own understandings and clarifications of assumptions, they experiment with and 
eventually take ownership of new skills and ideas. All along, the "guide on the side" serves to focus and deepen the dialogue without getting in the way of participants development of their own expertise.

In Web based learning, weekly "Conferences" are uniquely suitable to foster a dialogue where students develop their own understanding. Through this dialogue a student has an opportunity to make personal meaning of what they have read and thus generate new knowledge.

As in the face-to-face class, the online version of the course begins each week with students reading and considering the same original source essays. Then, in place of the in-class face-to-face group break out, students interact in an online dialogue in the "Conference" area of the course site over the same questions that have been posed in the face-to-face class.

The "For Conference Dialogue" questions are intended to help frame and begin the class dialogue, but the dialogue is not be limited to these questions. By Monday each student is to have read the assigned readings for that week. Due on Monday is an "initial post" to the Conference in which the student shares their thoughtful engagement with the material for that week. Again, the key to learning through dialogue is that students sustain attention, inquiry, and reflection on the topic for a full week. So, Tuesday through Thursday, each student is expected to engage his or her classmates and to sustain dialogue threads by reflecting on and inquiring into what others have posted. Through this "inquiry and reflection" component of the course requirements, students together create knowledge and understanding that no individual in the class originally had.

The professor, playing the part of the "guide on the side," does not directly engage students in the Conference; rather, two components take the place of the professor's face-to-face lectures. The first component is topic notes that are posted and available for students to read as they begin the weekly reading assignment. The second component is the professor's "Looking Forward, Looking Back" post which appears each Saturday at the end of the topic week. The "Looking Forward, Looking Back" posts are intended to place the class dialogue in a larger perspective and clear up any errors that remain after the "inquiry and reflection" portion of the week. A typical post is seven to ten pages in length.

The following is excerpted from the "Domestic and Global Business Environment" web syllabus:

A good Conference dialogue advances your understanding and that of your classmates. Your postings demonstrate preparation when you share your ideas about the readings; relate readings to your work or personal experience or other reading that you have done; share genuine and thoughtful opinions; restate your understanding of the thoughts expressed by your classmates; ask for clarification; pose probing questions; respond to the probing questions of others; uncover, articulate, and challenge assumptions; and propose alternative interpretations based upon reasoned, analytical thinking. Using specific quotations from the readings to support your analysis and views will advance your understanding and will give your classmates a better idea of what your position is based on. This will then facilitate the dialogue.

Thus, in an online context, learning takes place in an iterative process where students consider the points made by classmates and inquire and reflect on them. When students value the inquiry and reflection portion of the weekly online class dialogue, they set an intention of gaining additional insight and perspective. Through the dialogue they become aware of assumptions that they are making about classmates' postings. This sets the conditions for genuine insight and thus grows new knowledge.

There are several things the professor can do to insure that students are fully engaged in the weekly "Conference" They are:

- $\quad$ The syllabus clearly states that the Conference work count $33.33 \%$ of the their grade

- $\quad$ The syllabus clearly states that 4 absences (Conference work below the minimum standard) can result in a FA grade (failure to attend)

- $\quad$ Students are given weekly personal feedback on their performance. 
- Students who remain unwilling or unable to follow the weekly course rhythm are encourage to reevaluate their commitment to the course and drop if necessary

Why is the Conference work emphasized? Unfortunately, many students begin a web course believing that it will be a time saver for them. Or, they may come into the web-course having had experiences with web courses that were self-study courses, and they assume that all web courses are self-study. Neither assumption is true. Since a robust dialogue is essential for an effective web learning environment, the professor's role as the "guide on the side" means the professor must design course rules that support dialogue and then administers those rules.

The ability to sustain a thread in a Conference dialogue is essential to the learning process and knowledge creation in a web course. Students' postings should demonstrate the inquiry and reflection skills they are developing; their contributions should help the class work together with ideas and thus sustain threads in the dialogues.

At its very best, learning is an emergent phenomenon that takes place through interaction in a community where both the student and professor are learners. Perhaps the professor is more than a few steps ahead of the student; but as active learners, professors are traveling the same road as their students. As fellow travelers, they are co-creating an atmosphere where new knowledge can emerge.

\section{CONCLUSIONS}

Although face-to-face teaching pedagogy has moved significantly beyond the passive "tell them and test them" pedagogy of the "sage on the stage," web teaching represents a further evolution toward a teaching pedagogy where students play a greater role in helping new knowledge emerge. The fact that no significant differences in learning outcomes were observed between the two courses investigated in this study portends a bright future for web learning. Web teaching pedagogy is still in the early years of development. Ultimately, because a greater role is played by students in a web course when the course is designed to support dialogue, we believe there is a promising upside potential to web learning.

\section{AUTHOR INFORMATION}

Barry Brownstein is a professor of economics and CSX Distinguished Professor of Leadership at the University of Baltimore. In addition, he has taught at Rutgers, Harvard, and Fairleigh Dickinson Universities. He is known for his quality innovative teaching in both classroom and corporate seminar settings and has won numerous teaching awards. Although his Ph.D. (Rutgers University) is in economics, his teaching and research bridges two areas: economics and leadership. He is the author of numerous articles, editor of two books and is currently completing a leadership book titled: The Inner-Work of Leadership: A Guide to Personal and Organizational Transformation.

Deborah Brownstein received her Ph.D. in marketing from the University of Maryland. She has taught at the University of Baltimore and Georgetown University. Currently she is an educational consultant. She has received numerous teaching awards and her published research has appeared in journals such as European Journal of Marketing, Journal of Long Range Planning as well as anthologies such as Advances in Customer Relation Marketing.

Daniel A. Gerlowski is currently a Professor of Economics at the University of Baltimore. He earned his Ph.D. from the University of Pittsburgh in 1987. In addition to a faculty role, Gerlowski served for 9 years as Associate Dean and one year as Interim Dean in the Merrick School of Business. He has authored 20 academic journal articles and written two textbooks in Managerial Economics. Most recently he began working on his university's ERP implementation. His research interests include: applied Micro-Economics, and teaching and learning. 


\section{REFERENCES}

1. Allen, M., Bourhis, J., Mabry, E., Burrell, N., \& Timmerman, C. (2006). Comparing Distance Education to Face-to-Face Methods of Education. Classroom Communication and Instructional Processes: Advances Through Meta-Analysis (pp. 229-244). Mahwah, NJ, US: Lawrence Erlbaum Associates Publishers.

2. Bento, R; Brownstein, B.; Schuster, C. \& Zacur, S. (2005). Fostering Online Student Participation. Journal of College Teaching and Learning, 2 (7):31-37.

3. Bezjian, Vicken A. (2005) Consumer Expectations of Quality in Master of Business Administration Programs: A Comparison Between Face-to-Face Learning and Web-Delivered Distance Learning in Schools of Business. D.B.A. dissertation, Alliant International University, San Diego, United States -California. Retrieved September 29, 2008, from Dissertations \& Theses: Full Text database. (Publication No. AAT 3173422).

4. Brown, B.W. and C.E. Liedholm (2002) Can Web Courses Replace the Classroom in Principles of Microeconomics? The American Economic Review, 92(2): 444-449.

5. Coates, D. and B.R. Humphreys (2003) An Inventory of Learning at a Distance in Economics. Social Science Computer Review, 21(2): 196-207.

6. Collison, G; Elbaum, B; Haavind, S; Tinker, R. (2000) Facilitating Online Learning Madison, WI: Atwood Publishing

7. Harmon, Oskar and James Lambrinos (2007) Student Performance in Traditional vs. Online Format: Evidence from an MBA Level Introductory Economics Class. (University of Connecticut Department of Economics Working Paper) Storrs, CT: University of Connecticut

8. Hayek, F. (1945) The Use of Knowledge in Society. American Economic Review 35 (September): 519-30

9. Terry, Neil (2007) Accessing Instructor Modes for Master of Business Administration (MBA) Courses. Journal of Education for Business, 82(4) 220-25.

10. Topper, A. (2007, December). Are they the same? Comparing the Instructional Quality of Online and Faceto-Face Graduate Education Courses. Assessment \& Evaluation in Higher Education, 32(6), 681-691.

11. Warren, L., \& Holloman, H. (2005, June). On-line Instruction: Are the Outcomes the Same? Journal of Instructional Psychology, 32(2), 148-151. 